Archives de sciences sociales des religions

172 | octobre-décembre

Bulletin Bibliographique

\title{
La Fable mystique II de Michel de Certeau
}

\section{La rédaction}

\section{OpenEdition}

Journals

Édition électronique

URL : http://journals.openedition.org/assr/27218

DOI : $10.4000 /$ assr. 27218

ISSN : $1777-5825$

Éditeur

Éditions de l'EHESS

Édition imprimée

Date de publication : 1 octobre 2015

Pagination : 45

ISBN : 978-2-7132-2515-4

ISSN : 0335-5985

Référence électronique

La rédaction, "La Fable mystique II de Michel de Certeau », Archives de sciences sociales des religions [En ligne], 172 I octobre-décembre, mis en ligne le 01 octobre 2015, consulté le 23 septembre 2020. URL : http://journals.openedition.org/assr/27218; DOI : https://doi.org/10.4000/assr.27218 


\section{La Fable mystique II de Michel de Certeau}

Le Centre d'anthropologie religieuse européenne de l'École des hautes études en sciences sociales a réuni le 12 novembre 2013 une table ronde, introduite par Pierre Antoine Fabre, lors de laquelle, par ordre de parole, Dominique Julia, Jocelyne Sfez, Patrick Goujon, Jacques Le Brun (deux générations, quatre spécialistes de l'histoire culturelle de l'Europe moderne) ont présenté quatre lectures du second tome de La Fable mystique de Michel de Certeau, qui venait de paraître. François Trémolières a introduit ensuite la discussion qui suivit par une série de réflexions qu'on retrouvera à la suite des quatre interventions qui, toutes les quatre, chacune à leur manière, retissent les fils qui relient l'un à l'autre, pardelà la mort de leur auteur et plus de trente ans passé, les deux tomes de $\mathrm{La}$ Fable mystique, dont le premier était paru en 1982. La Revue remercie vivement les participants de cette table ronde d'avoir bien voulu donner forme écrite à leur intervention et de rejoindre ainsi, sous la forme de cette singulière polyphonie, le Bulletin bibliographique de la Revue.

La Rédaction 
